\title{
Evaluation of Hygiene Quality in Ripened Cheeses Marketed in Transylvania Area
}

\author{
Gabriel VALASUTEAN, Alexandra TABARAN*, Sorin Daniel DAN, Oana REGET, Marian MIHAIU \\ Faculty of Veterinary Medicine, University of Agricultural Sciences and Veterinary Medicine, Mănăștur \\ Street, no.3/5, Cluj-Napoca, Romania; \\ Corresponding author: lapusan_alexandra@yahoo.com
}

Bulletin UASVM Veterinary Medicine 72(1) / 2015,

Print ISSN 1843-5270; Electronic ISSN 1843-5378

DOI:10.15835/buasvmcn-vm: 11096

\begin{abstract}
Milk and dairy products represent potential nutritive environment for the growth of some pathogen bacteria such as Salmonella spp., Escherichia coli, Staphylococcus aureus. Our study aimed to assess the incidence of pathogen bacteria through classical and molecular methods in order to perform a risk analysis in Transylvanian production area. The material was represented by 160 ripened dairy products from the following categories: soft, medium-hard and hard. We have isolated E.coli in 121 samples (75.62\%), which represent a concerning number. All the samples were confirmed by PCR method targeting the stress protein A gene sequence. No positive samples were found for Salmonella spp. and Staphylococcus aureus. At the risk analysis performed there was a medium level of probability and gravity for consumer contamination with pathogenic E.coli by consumption of dairy products. It was concluded that further studies are needed in order to assess the toxicity of the E.coli strains isolated from the dairy products investigated so as to accurately assess the risk for contamination. A more rigorous hygiene during the milking and manufacturing of dairy products is recommend, especially within the traditional systems.
\end{abstract}

Keywords: bacteria, cheese, milk, PCR .

\section{INTRODUCTION}

Cheese production holds a long time tradition in Europe. Between 1995 and 2004 cheese production increased by nearly $15 \%$ and almost $40 \%$ of the milk produced in Europe is consumed as cheese. According to the latest European Union statistics Italy, France and Netherlands are the most important producers of dairy products (EC, 2014). The market of dairy food in Romania increased over time, however due to small to very small farms the production is still low compared to other European countries (EC, 2012).

In raw milk as well as in the dairy products processed from it, the microorganisms can develop rapidly due to their high nutritive content. Earlier researches on the microbiological quality of dairy products have revealed the possible presence of a wide range of bacteria, such as: Salmonella spp., Listeria monocytogenes, Campylobacter jejuni, Yersinia enterocolitica, pathogenic strains of Escherichia coli and enterotoxigenic strains of Staphylococcus aureus (Tatini and Kauppi, 2002). As consequence, the sanitary veterinary control programs to asses the hygiene quality of dairy products are often applied within the production chain in order to minimize the risk of infecting the consumer.

In order to be able to implement an efficient control strategy there is an obvious need for accurate and rapid analysis methods. The molecular techniques, such as polymerase chain reaction (PCR) method, have been used currently in the identification and confirmation of bacteria isolated from various food products (Messelhäusser et al., 2011, Meyer et al., 1995, Ong et al., 2007, Pan et al., 2007, Pansiot et al., 2011, Yang et al., 2003). Due to its proved efficiency, this method has a strong potential of being implemented as an international standard for bacteria isolation (Nollet et al., 2011). 
The aim of our study was to assess the incidence of pathogen bacteria through classical and molecular methods in order to perform a risk analysis within the Transylvania area. The results obtained will constitute a data base which can serve in further studies on the possible contamination pathways with these bacteria, as well as development of HACCP programs.

\section{MATERIALS AND METHODS}

The study comprised 160 ripened dairy products such as: soft (Brie cheese), medium hard cheese (telemy), hard cheese. The products were purchased from the traditional market and also hypermarkets found in Transylvania area. All the samples were kept in their original package and at $4^{\circ} \mathrm{C}$ until their analysis.

Bacteria isolation through classical methods

Samples were investigated in terms of E.coli, Salmonella spp., coagulase-positive staphylococci, Clostridium spp., Listeria monocytogenes. The isolation of bacteria was performed according to the national standards (SR ISO 7251/96; SR EN ISO 6888/3/2006; SR EN ISO 6579/AC/2006; SR ISO 4833/2003; SR ISO 11290-1/2000).

PCR technique for bacteria confirmation

DNA extraction protocol: The DNA extraction protocol followed the steps previously published by Lapusan (2012). Briefly, $150 \mu \mathrm{l}$ of CHELEX reagent (Biorad, Germany) (10\%) was used for the inoculation of bacteria colonies. The temperatures used for cell membrane lyses were $56^{\circ}$ for $30^{\prime}$ and $92^{\circ}$ for 5 '.

PCR protocol: The samples were amplified in a final volume of $25 \mu \mathrm{l}$, each containing: $12,5 \mu \mathrm{l}$
MyTaq (Bioline, England), $1 \mu \mathrm{l}$ primer Forward; $1 \mu \mathrm{l}$ primer Reverse, $4 \mu \mathrm{l}$ ADN şi 6,5 $\mu \mathrm{l}$ pure water for PCR (Sigma, Germany). The primers used in the PCR protocol are presented in Tab. 1.

\section{The statistical evaluation:}

The statistical evaluation was performed in order to evaluate the possible differences in meat composition among the individuals studied. This evaluation was done by performing the ANOVA test (Origin 8.5 software, USA).

\section{RESULTS AND DISCUSSION}

The results obtained after the evaluation of pathogen bacteria within the dairy products marketed in the free market, respectively hypermarkets are shown in Tab. 2 .

The germ incidence belonging to the studied bacteria species in dairy buffalo products collected from the free market and commercial units (hypermarkets).

Within the samples collected from the free market, a high prevalence of E.coli bacteria was noticed. The statistical analysis revealed significant differences $(\mathrm{p}<0.05)$ among the values obtained in the case of all three categories of cheese purchased from the free market compared to the ones obtained from hypermarkets.

The high percentages of E.coli bacteria found in the samples collected from the traditional market might be explained by the conditions of processing which sometimes lack in a proper hygiene during milking or actual manufacturing. All bacteria isoated through classical method was confirmed by PCR (Fig.1).

Tab.1. Primers and targeted genes used in the confirmation of bacteria

\begin{tabular}{cccc}
\hline Microorganism & \multicolumn{1}{c}{ Primer sequence } & $\begin{array}{c}\text { Target Gene } \\
\text { product's size/bp) }\end{array}$ & Bibliographic reference \\
\hline E.coli & $\begin{array}{c}\text { CCGATACGCTGCCAATCAGT } \\
\text { ACGCAGACCGTAAGGGCCAGAT }\end{array}$ & $\begin{array}{c}\text { Universal stress } \\
\text { protein A (884) }\end{array}$ & Osek (2001) \\
\hline Salmonella & $\begin{array}{c}\text { TGTTGTGGTTATAACCGCA (F) } \\
\text { CACAAATCCATCTCTGGA (R) }\end{array}$ & 16S ARNr (571) & Lin and Tsen (1995) \\
\hline $\begin{array}{c}\text { L. monocytogenes } \\
\text { Staphyloccocus } \\
\text { aureus }\end{array}$ & $\begin{array}{c}\text { GACATTCAAGTTGTGAA (F) } \\
\text { CGCCACACTTGAGATAT (R) }\end{array}$ & Listeriolizina 0 (560) & Thomas et al. (1991) \\
\hline
\end{tabular}


Other studies have indicated also a high prevalence of E.coli in dairy products. Araujo et al. (2002) have revealed $21.1 \%$ of enteropathogenic E.coli in the cheese samples marketed in Brazil. In Egypt, traditional cheese samples revealed the presence of E.coli in 75\%. In Iraq, Abbar and Kaddar (1991) have reported $40.5 \%$ of the cheese samples contaminated with enteropathogenic E.coli strains. Our study did not focus on the evaluation of the E.coli toxicity properties but given the high number of positive samples such a research would be needed in order to perform a more accurate risk analysis. From all the rennet - coagulated cheese categories, the soft ones revealed the poorest quality in terms of E.coli presence.

Our risk analysis has shown a medium probability and gravity of contamination with
E.coli through the consumption of dairy products. This risk analysis was performed taking into consideration the processing conditions, such as methods of manufacturing, transport, manipulation and marketing which at this moment are deficitery in case of traditional production. Dairy products obtained from raw milk have an even higher probability of contamination given the lack of hygiene measures taken within milking and manufacturing in these small scale units. Compared to the prevalence of E.coli isolated from dairy products sold within the traditional markets we revealed a lower number in the case of those sold within hypermarkets. The product which is the most exposed to contamination was revealed to be soft cheese (freshly obtained, melted cheese).

No samples revealed the presence of Salmonella spp. or Staphilococcus aureus. The

Tab. 2. Results obtained at the microbiological evaluation of cheese products obtained from the free market and hypermarkets

\begin{tabular}{|c|c|c|c|c|c|c|}
\hline \multirow[b]{2}{*}{ Product } & \multirow[b]{2}{*}{ Microorganism } & \multicolumn{2}{|c|}{ Free market } & \multicolumn{2}{|c|}{ Hipermarketuri } & \multirow[b]{2}{*}{ ANAOVA } \\
\hline & & $\begin{array}{l}\text { Positive } \\
\text { samples }\end{array}$ & $\%$ & Positive samples & $\%$ & \\
\hline \multirow{3}{*}{ Soft cheese } & Staphylococcus aureus & 0 & 0 & 0 & 0 & - \\
\hline & E. coli & 63 & 39.37 & 8 & 5 & * \\
\hline & Salmonella spp. & 0 & - & - & - & - \\
\hline \multirow{3}{*}{$\begin{array}{l}\text { Medium - } \\
\text { hard cheese }\end{array}$} & E. coli & 21 & 13.12 & 11 & 6.87 & * \\
\hline & Salmonella spp. & 0 & - & - & - & - \\
\hline & Stapylococcus spp. & 0 & - & - & - & - \\
\hline \multirow{3}{*}{ Hard cheese } & E. coli & 14 & 8.75 & 4 & 2.5 & $*$ \\
\hline & Salmonella spp. & 0 & - & - & - & - \\
\hline & Stapylococcus spp. & 0 & - & - & - & - \\
\hline
\end{tabular}

$* \mathrm{p}<0.05$

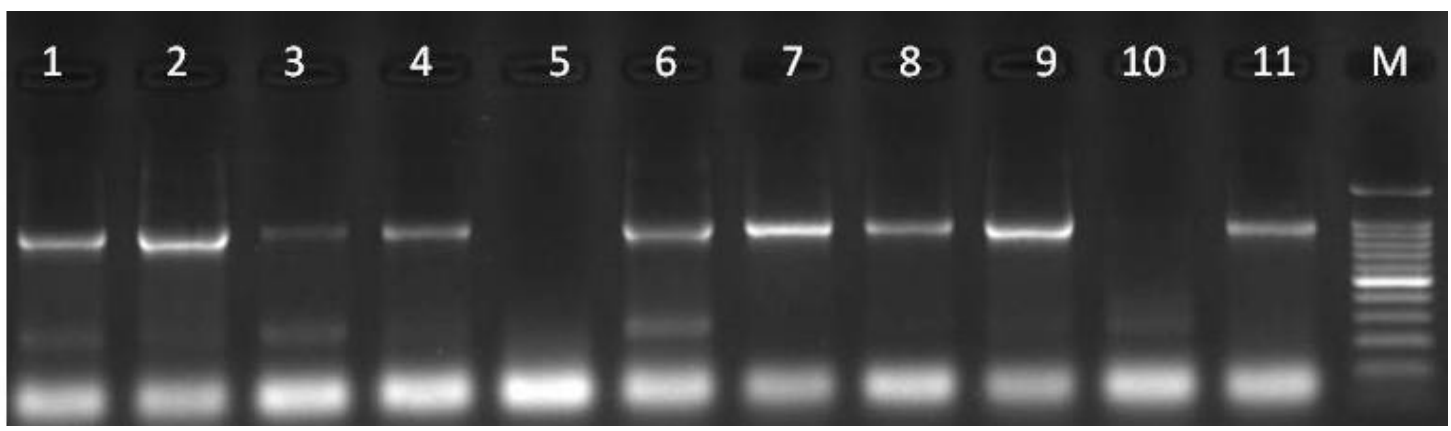

Fig.1. Electrophoretic profile of $884 \mathrm{bp}$ fragment corresponding to E.coli isolated from dairy products; line 1 - 4; 6 - 9 positive samples; line 5 negative sample; line 10 negative control; line 11 positive control (reference E.coli strain). 
absence of Salmonella spp. and Staphilococcus aureus contamination in this study, in contrast with the high prevalence of E.coli, was probably due to the different ecologies of these bacteria. E.coli are bacteria which normally are introduced in dairy products by contamination of the raw milk. The pathogen strain of E.coli 0157:H7 has shown survival and prevalence on stainless-steel surfaces (Salo et al. 2006) which leads us to the idea that contamination from surfaces in the large scale production units is possible. Mucchetti et al. (2008) has revealed high levels of E. coli in Vasteda cheese due to the post-contaminations in the dairy plants. Another study conducted by Aygun et al. (2005) found similar results when examining Carra Turkish cheese. the processing, ripening and storage should be carried out under good hygienic conditions in the production.

\section{CONCLUSION}

The high prevalence of E.coli bacteria in the ripened cheese samples examined lead us to the conclusion that the processing, ripening and storage of these products should be carried out under better hygienic conditions. The absence of Salmonella spp. and Staphilococcus aureus shows that these products represent a low risk for contamination which such bacteria. Studies should be extended on assessing the toxicity of the E.coli strains isolated from these products in order to perform an accurate risk analysis.

Acknowledgments. This paper was published under the frame of European Social Fund, Human Resources Development Operational Programme 2007-2013, project no.POSDRU/159/1.5/S/ 136893.

\section{REFERENCES}

1. Abbar F, Kaddar HK (1991). Bacterological studies on Iraqi milk products. J Appl Bacteriol 71:497-500.

2. Araujo S, Pagliares A, Queiroz L, Fritas-Almeida A (2002). Occurrence Staphylococcus and enteropathogens in soft cheese commercialized in the city of Rio de Janeiro Brazil. J Appl Microbiol 92:1172-7.

3. Aygun 0, Aslantas O, Oner S (2005). A survey on the microbiological quality of Carra, a traditional Turkish cheese. J Food Eng 66:401-404.

4. EC (European Comission) (2014) 29 \& 30 September 2014 - Brussels, available at http://www.google.ro/url? $\mathrm{sa}=\mathrm{t} \& \mathrm{rct}=\mathrm{j} \& \mathrm{q}=\& \mathrm{esrc}=\mathrm{s} \&$ source $=$ web $\& \mathrm{~cd}=10 \& \mathrm{ved}=0 \mathrm{CG}$ kQFjAJ\&url=http $\% 3 \mathrm{~A} \% 2 \mathrm{~F} \% 2 \mathrm{Fwww}$.eucolait.be $\% 2$ Fallfiles $\% 2$ Fstatistics $\% 2$ Feucolait-meetings $\% 2$ F14994september-meetings

5. EC (European Comission) (2012), EU dairy farms report 2012 based on FADN data, available at http://ec.europa. eu/agriculture/rica/pdf/Dairy_report_2012.pdf

6. Lapusan A (2012). Researches concerning the quality and authenticity markers certified in the tracebility of buffalo milk and dairy products. PhD thesis.

7. Messelhäusser U, Kämpf P, Colditz J, Bauer H, Schreiner H, Höller C, Busch U (2011). Qualitative and quantitative detection of human pathogenic Yersinia enterocolitica in different food matrices at retail level in Bavaria. Foodborne Pathog Dis 1: 39-44.

8. Meyer R, Hofelein C, Lüthy J, Candrian U (1995). Polymerase chain reactionrestriction fragment length polymorphism analysis: a simple method for species identification in food. J Assoc Off Anal Chem Int 78: 15421551.

9. Mucchetti G, Bonvini B, Remagni MC, Ghiglietti R, Locci F, Barzaghi S, Francolino S, Perrone A, Rubiloni A, Campo P, Gatti M, Carminati D (2008). Influence of cheesemaking technology on composition and microbiological characteristics of Vastedda cheese. Food Contam 19:119125.

10. Ong SB, Zuraini MI, Jurin WG, Cheah YK, Tunung R, Chai LC, Haryani Y, Ghazali FM, Son R (2007). Meat molecular detection: sensitivity of polymerase chain reactionrestriction fragment length polymorphism in species differentiation of meat from animal origin. ASEAN Food Journal 14: 51-59.

11. Pan Y, Breidt Jr. (2007). Enumeration of viable Listeria monocytogenes cells by real-time PCR with propidium monoazide and ethidium monoazide in the presence of dead cells. Appl Environ Microbiol 73:8028-8031.

12. Pansiot J, Chaouachi M, Cavellini L, Romaniuk M, Ayadi M, Bertheau Y, Laval V (2011). Development of two screening duplex PCR assays for genetically modified organism quantification using multiplex real-time PCR master mixes. 2011. Eur Food Res Technol 232:327-334.

13. Tatini SR, Kauppi KL (2002). A faster and more economical alternative to the standard plate count method for microbiological analyses of raw milk. Commun Curr Res Educ Topics Trends Appl Microbiol, 19:397- 405.

14. Nollet LML, Toldrá F (2011). Safety analysis of Food of animal origin, CRC Press Taylor \& Francis Group, NY, chapter III, 812.

15. Salo S, Ehavald H, Raaska L, Vokk R, Wirtanen G (2006). Microbial surveys in Estonian dairies. LWT Food Sci Technol 39:460-471.

16. Yang C, Jiang Y, Huang K, Zhu C, Yin Y (2003). Application of real-time PCR for quantitative detection of Campylobacter jejuni in poultry, milk and environmental water. FEMS Immunol Med Microbiol. 38:265-271. 